\title{
27. A korlátlan államhatalom sajátos korlátja: a különleges jogrend Kínában ${ }^{1}$
}

\author{
DORNFELD LÁSZLÓ
}

\section{A különleges jogrend alkotmányos és törvényi szintú szabályozása és esetkörei}

Kína ma hatályos, 1982-es alkotmánya ${ }^{2}$ meglehetősen szúkszavúan foglalkozik a különleges jogrend kérdésével, azt nem tölti ki részletes tartalommal. Az Országos Népi Gyúlés (az ország törvényhozása) évente mindössze két hétig ülésezik plenárisan, ${ }^{3}$ egyéb időszakokban annak Állandó Bizottsága gyakorolja feladat- és hatásköreit. Tagjai egy elnök, alelnökök, a fốtitkár, valamint a törvényhozás bizonyos képviselői (míg a plenáris ülésen 2980,

I A fejezetben a kínai szavak és nevek átírása a pinyin kínai fonetikus ábécével történik. Kivételt képeznek a már rögzült alakok (például Peking, Mao Ce-tung), amelyek ismert formájukban kerülnek feltüntetésre.

2 A Kínai Népköztársaság alkotmányát (中华人民共和国宪法, Zhonghua Renmin Gongheguo Xianfa) 1982ben fogadták el. Ez a negyedik alkotmány az ország történelmében a sztálinista mintájú 1952-es, majd a „négyek bandája” nevével fémjelzett 1975-ös és a rövid ideig hatályban lévő 1978-as alkotmányok után. Az alkotmány ugyan az 1977-es szovjet alkotmányt követi, ám a Teng Hsziao-ping nevével fémjelzett reformidőszak során került elfogadásra, így például olyan rendelkezéseket tartalmaz, mint az alkotmány primátusa, valamint a Kínai Kommunista Párt alkotmányos keretek között meghatározott tevékenysége. Az így létrejött sajátos modellt egyesek „egypárti alkotmányosságként” definiálják (Shigong, 2014; Spitzer, 2020, 284. 0.).

3 Alkotmány 61. cikk.

Dr. Dornfeld László

laszlo.dornfeld@mfi.gov.hu

kutató (Mádl Ferenc Összehasonlító Jogi Intézet)

Dornfeld, L. (2021) 'A korlátlan államhatalom sajátos korlátja: a különleges jogrend Kínában' in Nagy, Z., Horváth, A. (szerk.) A különleges jogrend és nemzeti szabályozási modelljei, 592-608. o. Budapest: Mádl Ferenc Öszszehasonlító Jogi Intézet.

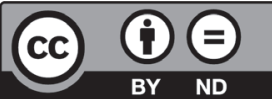


addig az Állandó Bizottság munkájában 175 képviselő vesz részt). Az Állandó Bizottság hatásköreivel foglalkozó részben az alkotmány ennek a szervnek a hatáskörébe utalja a hadiállapot, ${ }^{4}$ illetôleg a szükségállapot ${ }^{5}$ bevezetésének lehetôségét. ${ }^{6} \mathrm{~A}$ különleges jogrend bevezetésérôl szóló döntés alapján az államelnök hirdeti ki azt. ${ }^{7}$ Ezalól kivételt jelentenek a központi kormányzat igazgatása alatt álló tartományok, autonóm területek és városok, amelyek esetén az Államtanács (vagyis a központi kormány) dönt a szükségállapot bevezetéséról. ${ }^{8}$

Fontos megjegyezni, hogy Hongkong és Makaó saját speciális jogrenddel rendelkezik, amelynek részeként saját alaptörvényük van, eltérô jogrendszerrel és közigazgatással rendelkeznek, és ezeken a területeken a különleges jogrend bevezetésével kapcsolatos szabályok is eltérőek. A hongkongi alaptörvény rendelkezése a törvényhozás Állandó Bizottsága számára teremt lehetőséget a hadiállapot elrendelésére, illetve a szükségállapot bevezetésére olyan zứrzavar miatt, amely veszélyezteti a nemzeti egységet vagy biztonságot, és amely nem áll a régió kormányának ellenőrzése alatt. ${ }^{10} \mathrm{~A}$ makaói alaptörvény ${ }^{11}$ gyakorlatilag szóról szóra ugyanezt a rendelkezést tartalmazza. ${ }^{12}$

Ezeket a rendelkezéseket különböző törvények töltik meg tényleges tartalommal. Kiemelendő ezek közül a veszélyhelyzeti intézkedési törvény, ${ }^{13}$ az ostromállapotról szóló törvény, ${ }^{14}$ valamint a honvédelmi törvény. ${ }^{15}$

4 Az Alkotmány a zhanzheng zhuangtai kifejezést használja, hivatalos angol fordításban state of war.

5 Az Alkotmány a jinji zhuangtai kifejezést használja, hivatalos angol fordításban state of emergency.

6 Alkotmány 67. cikk 19-20. pont.

7 Alkotmány 80. cikk.

8 Alkotmány 89. cikk 16. pont.

9 A Kínai Népköztársaság hongkongi különleges közigazgatási régiójának alaptörvényét (中华人民共和国香 港特别行政区基本法, Zhonghua Renmin Gongheguo Xianggang Tebie Xingzhengqu Jibenfa) 1990-ben fogadták el, és 1997-ben, a terület Nagy-Britanniától történő visszatérését követően lépett hatályba.

10 Hongkongi alaptörvény 18. szakasz.

11 A Kínai Népköztársaság makaói különleges közigazgatási régiójának alaptörvényét (中华人民共和国澳门特 别行政区基本法, Zhonghua Renmin Gongheguo Aomen Tebiexingzhengqu Jibenfa) 1993-ban fogadták el, és a terület Portugáliától történő 1999-es visszatérését követően lépett hatályba.

12 Makaói alaptörvény 18 . cikk.

13 A törvényhozás Állandó Bizottsága által 2007. augusztus 30-án elfogadott, az államelnök 69. sz. határozatában kiadott veszélyhelyi intézkedési törvény (中华人民共和国突发事件应对法, Zhonghua Renmin Gongheguo Yingdui Fa) (a továbbiakban: Veszélyhelyzeti tv.).

14 A törvényhozás Állandó Bizottsága által 1996. március 1-jén elfogadott, az államelnök 61. sz. határozatában kiadott ostromállapotról szóló törvény (中华人民共和国戒严法, Zhonghua Renmin Gongheguo Jieyan Fa) (a továbbiakban: Ostromállapot tv.).

15 A törvényhozás Állandó Bizottsága által 1997. március 14-én elfogadott, az államelnök 84. sz. határozatában kiadott honvédelmi törvény (中华人民共和国国防法, Zhonghua Renmin Gongheguo Guofang Fa) (a továbbiakban: Honvédelmi tv.). 
A szükségállapot vonatkozásában az Ostromállapot tv. ${ }^{16}$ és a Veszélyhelyzeti tv. tartalmaz rendelkezéseket. Hivatalosan mindkét törvény hatályban van, ${ }^{17}$ annak ellenére, hogy más-más terminológiát használnak, illetőleg a bevezetés kapcsán ellentétes szabályokat tartalmaznak. A szükségállapot a korábbi helyzetek elégtelen kezelése miatt került bevezetésre a kínai jogrendszerben az ostromállapot felváltására, ami egyúttal a katonai helyett a civil válságkezelés felé tolta el a különleges helyzetek kezelését. ${ }^{18} \mathrm{Az}$ új törvényt pontosan az Ostromállapot tv. 2003-as SARS-járvány során tapasztalható elégtelenségei miatt fogadták el, amely során egyértelmúvé vált, hogy az Ostromállapot tv. rendelkezései nehezen alkalmazhatók nem tradicionális fenyegetések (például terrorizmus, fertőző betegségek) esetén. ${ }^{19}$ Ugyanakkor külföldi kommentátorok a korábbi szabályozás egyfajta „kiterjesztéseként” értelmezik az új szabályozást. ${ }^{20}$ Ezen jogi bizonytalanságok alapján mindkét törvény szabályozása bemutatásra kerül.

Az Ostromállapot tv. alkalmazására akkor nyílik lehetőség, ha olyan rendkívüli helyzet következik be, mint társadalmi zúrzavar, lázadás vagy súlyos zavargások, amelyek súlyosan veszélyeztetik a nemzet egységét és biztonságát vagy a közbiztonságot, és amelyek mellett a közrend nem tartható fenn, és az emberek életének és vagyonának biztonsága rendkívüli intézkedések meghozatala nélkül biztosított. ${ }^{21} \mathrm{~A}$ bevezetéssel kapcsolatban a törvény megismétli az alkotmány rendelkezéseit, hozzátéve, hogy az Államtanács által bevezetett szükségállapot esetén a miniszterelnök hirdeti ki azt. ${ }^{22} \mathrm{~A}$ szükségállapot idején alkalmazható eszközök kapcsán a törvény meglehetősen általánosan fogalmaz: az érintett területen az állam e törvénynek megfelelően különleges szabályokat és előirásokat határozhat meg az állampolgárok jogainak és szabadságának gyakorlására vonatkozóan, ${ }^{23}$ valamint az érintett terület kormányzata meghozza a közrend mielőbbi normalizálásához, az emberek életének és vagyonának biztonságához, valamint a napi szükségleteik ellátásához szükséges intézkedéseket. ${ }^{24}$ Ezen túlmenően a törvény a természetes és jogi személyek számára kötelezettségként határozza meg, hogy szigorúan be kell tartaniuk ezeket a rendelkezéseket, és aktívan segíteniük kell a szerveket a közrend normalizálásában. ${ }^{25} \mathrm{~A}$ különleges jogrendi szabályok biz-

16 A törvény az ostromállapot (jieyan, Delisle fordításában state of siege) kifejezést használja, amely a 2004-es alkotmányreform előtt az alkotmányban is szerepelt. Ugyan tervben volt egy szükségállapoti törvény elfogadása is, erre végül mégsem került sor (Delisle, 2010, 405-406. o.).

$17 \mathrm{Az}$ ILO oldalán szereplő országjelentés is ezt erősíti meg. Elérhető: www.ilo.org/dyn/irlex/en/ f?p=14100:1100:0::NO::P1100_ISO_CODE3,P1100_SUBCODE_CODE,P1100_YEAR:CHN,,2015 (Letöltve: 2020. december 15.).

18 Jianfu, 2004.

19 Deloise, 2010, 420. o.

20 Elérhető: www.loc.gov/law/help/health-emergencies/china.php (Letöltve: 2020. december 15.).

21 Ostromállapot tv. 2. szakasz.

22 Ostromállapot tv. 3. szakasz.

23 Ostromállapot tv. 4. szakasz.

24 Ostromállapot tv. 5. szakasz.

25 Ostromállapot tv. 6. szakasz. 
tosítását a Népi Rendőrség, illetőleg a Népi Fegyveres Rendőrség biztosítja, az Államtanács pedig javasolhatja a Népi Felszabadító Hadsereg bevetését. ${ }^{26}$

A szükségállapot megszervezésének a feladata az Államtanácsé, ha az országosan vagy a közvetlenül a központi kormány igazgatása alatt álló tartomány, autonóm terület vagy város területén kerül bevezetésre. Utóbbi esetben a tartományi közigazgatás feladata a tényleges tevékenységek megszervezése, ám indokolt esetben az Államtanács átveheti ezt a feladatot. ${ }^{27}$ Fel kell állítani egy speciális szervet, amely összehangolja az érintett egységek által a szükségállapoti feladatok ellátása érdekében tett intézkedéseket, és egységes terveket és intézkedéseket dolgoz ki a különleges jogrend érvényesítésére. A szükségállapoti feladatok ellátásában részt vevő katonai egységek katonai parancsnokság alatt maradnak. ${ }^{28}$

A szükségállapot kapcsán a másik fontos jogszabály a Veszélyhelyzeti tv., amely elsősorban a szükségállapot alatti szinteket szabályozza. Ezen törvény alapján ha egy különösen súlyos veszélyhelyzet történik, amely komoly veszélyt jelent az emberek életére vagy vagyonbiztonságára, a nemzetbiztonságra, a közbiztonságra, a környezetbiztonságra vagy a társadalmi rendre, és annak súlyos társadalmi kárát nem lehet megszüntetni vagy hatékonyan enyhíteni az e törvényben található enyhébb eszközök által, úgy a szükségállapot bevezetésének van helye. ${ }^{29} \mathrm{~A}$ két törvény egyaránt hatályban van mind a mai napig, mert bár az alkotmányos reform megváltoztatta a jogintézmény nevét, az Ostromállapot tv.-t nem helyezte hatályon kívül, azok rendelkezései pedig nem ellentétesek egymással.

A hadiállapot vonatkozásában a Honvédelmi tv. rendelkezéseit kell alkalmazni. A törvény a külső agresszió elleni felkészülés és fellépés, a fegyveres felforgatás meghiúsítása, az állam szuverenitásának, egységének, területi integritásának és biztonságának védelme érdekében folytatott katonai tevékenységek során alkalmazandó. ${ }^{30} \mathrm{~A}$ törvény 8 . fejezete tárgyalja a hadiállapotra vonatkozó szabályozást. Az állam az alkotmány értelmében hadiállapotot hirdet, különféle intézkedéseket fogad el az emberi, anyagi és pénzügyi erőforrások összpontosítására, és valamennyi állampolgárt vezet az ország védelme és az agresszió elleni ellenállás során. ${ }^{31}$ Itt a normatív részletszabályok egyáltalán nem kerülnek kifejtésre, ${ }^{32}$ ahogy az is érdekessége a jogszabálynak, hogy az államot egész egységként kezeli, míg az alkotmány kifejezetten a törvényhozás Állandó Bizottsága kezébe adja a hatalmat a hadiállapot kihirdetésére.

26 Ostromállapot tv. 8. szakasz.

27 Ostromállapot tv. 9. szakasz.

28 Ostromállapot tv. 10. szakasz.

29 Szükségállapoti törvény 69. szakasz.

30 Honvédelmi tv. 2. szakasz.

31 Honvédelmi tv. 44. szakasz.

32 Spitzer, 2020, 288. o. 


\subsection{A különleges jogrendre való felkészülést segító békeidejü szabályok és a kapcsolódó szervezetrendszer}

A különleges jogrendre való felkészülés szabályait elsősorban a Veszélyhelyzeti tv. tartalmazza. Ez azonban csak egy komponense a 2003-as SARS-járvány után életre hívott Állami Katasztrófavédelmi Rendszernek, amely négy pillérből áll (a kínai államigazgatásban népszerú szlogenek közül ez az „egy terv, három alrendszer” megnevezést kapta). Ebből az első, a „terv” megnevezés a Katasztrófaelhárítási Általános Állami Tervre vonatkozik, amelyet még 2003-ban hívtak életre. Emellett létezik 28 a különböző veszélyhelyzeti tervekből, amelyek eltérő kihívásokra (például természeti katasztrófák, balesetek, társadalmi zavarok) válaszolnak, illetve 160 szektorspecifikus veszélyhelyzeti terv, amelyek így együtt egy részletes tervezési rendszert alkotnak. ${ }^{33}$ Mindezek mellett különböző szinteken is tervek kerülnek kidolgozásra, 2015-ig mintegy 1,3 millió veszélyhelyzeti terv született meg. ${ }^{34}$

A második pillér a szervezeti rendszer, ahol az Államtanács szerepe a legjelentősebb, amely mind békeidőben, mind rendkívüli helyzetben az államszervezet csúcsán áll. A veszélyhelyzetek felmérése és kezelése érdekében speciális állandó irodákat hoztak létre helyi, illetve központi szinten is. A harmadik pillér két elv beépítése: az események szintekbe sorolása, illetve az információmegosztás. Végül a negyedik pillért a jogi szabályozás jelenti. ${ }^{35}$

A már említett Veszélyhelyzeti tv. tartalmazza a tervek készítésével és tartalmával kapcsolatos szabályokat, ${ }^{36}$ a potenciális veszélyforrások monitorozásának kötelezettségét, ${ }^{37}$ biztonságirányítási rendszer létrehozását és ellenőrzését írja elő, ${ }^{38}$ a veszélyes létesítményekért, illetve a tömegközeledésért vagy más, sok ember által használt közterületért felelős jogi személyek számára is előír vizsgálati, illetve elókészületi kötelezettségeket, ${ }^{39}$ a mentőcsapatok képzését, kijelölését és gyakorlatait határozza meg,40 illetve egyéb, a különböző rendszerek kialakításával és múködtetésével kapcsolatos kötelezettségeket is szab, valamint oktatási és ismeretterjesztő kampányokról is rendelkezik. ${ }^{41}$ Külön fejezet rendelkezik arról, hogy milyen módon kell az illetékes szerveknek figyelniük a potenciális veszélyeket, és a már meglévő veszélyhelyzeti terveket hogyan kell aktiválni és gyakorlatba ültetni veszélyhelyzet esetén. ${ }^{42}$

Ugyan elméletben ez a rendszer megfelelően felépítettnek tûnik, a gyakorlat azt mutatja, hogy számos problémától szenved. Például sem a vonatkozó törvény, sem az általános terv nem tartalmaz iránymutatásokat arra nézve, hogy a veszélyhelyzeti terveket miként kell

$33 \mathrm{Lu}-\mathrm{Xue}, 2016,415$. 0.

34 Shen et al., 2015, 271. 0.

$35 \mathrm{Lu}$-Xue, 2016, 418-419. o.

36 Veszélyhelyzeti tv. 17-18. szakasz.

37 Veszélyhelyzeti tv. 20. szakasz.

38 Veszélyhelyzeti tv. 22. szakasz.

39 Veszélyhelyzeti tv. 23-24. szakasz.

40 Veszélyhelyzeti tv. 25-28. szakasz.

41 Veszélyhelyzeti tv. 30-36. szakasz.

42 Veszélyhelyzeti tv. 37-62. szakasz. 
összeállítani, csakis a tartalmukat határozza meg. Az alacsonyabb szintú terveket gyakran a magasabb szint által kidolgozottról másolják le. Habár számszerúleg rengeteg különböző terv van, ezek között számos megegyező tartalmú létezik. A helyzetet tovább rontja, hogy a tervek készítői gyakran nem veszik elég komolyan ezt a kötelezettséget, a komolyabbnak itélt feladatokra koncentrálva inkább. ${ }^{43} \mathrm{~A}$ tervezési rendszer nagy hiányossága még az is, hogy csak a készítés pillanatában felismert veszély esetén alkalmazható, váratlan helyzetekben nem, márpedig a felkészülés alapját ez adja. ${ }^{44}$

\subsection{A válságkezelésre vonatkozó szabályok}

A válságkezelés szabályozását a veszélyhelyzeti intézkedési törvény tartalmazza, amely meghatározza a szükségállapotot el nem érő szintek kezelését. A jogszabály erre a veszélyhelyzet ${ }^{45}$ kifejezést alkalmazza, és olyan természeti és emberi katasztrófára, közegészségügyi eseményre vagy társadalmi biztonsági eseményre vonatkozik, amely véletlenül következett be, súlyos társadalmi kárt okozott vagy okozhat, és veszélyhelyzeti intézkedések elfogadására van szükség a kezelésük során. A törvény az esetkörök négy szintjét határozza meg csökkenő súlyossági sorrendben: különösen komoly, komoly, jelentős, rendes. ${ }^{46} \mathrm{~A}$ másodiktól a negyedik szintû́ veszélyhelyzetekkel kapcsolatos intézkedések szintjét a törvény a lehetô legalacsonyabban határozza meg, az érintett megye kormányzatánál. Amennyiben kettő vagy több megye érintett a veszélyhelyzet által, úgy az eggyel magasabb, prefektúrai szint a felelős a szükséges intézkedések megtételéért. A megyei kormányzatnak azonnal intézkedéseket kell tennie a veszélyhelyzet felmérése és kezelése érdekében, vagy amennyiben úgy ítéli meg, hogy az ebből eredő károk kezelése meghaladja az erőforrásait, úgy azonnal tájékoztatnia kell a magasabb közigazgatási szintet erről. ${ }^{47} \mathrm{Az}$ első, különösen komoly kategóriába tartozó veszélyhelyzet esetén a miniszterelnök vezetésével az Államtanács feladata a helyzet elemzése, az arra adott válasz kidolgozása és végrehajtása. Minden megyei vagy azon felüli szintû helyi kormányzat közösen létrehoz egy veszélyhelyzet-elhárítási parancsnokságot, amely az adott kormányzatok elnökeiből, a kapcsolódó részlegek vezetőiből, valamint a Népi Felszabadító Hadsereg, illetve a Népi Fegyveres Rendőrség helyi parancsnokából áll azzal a céllal, hogy egységesen vezesse és koordinálja a veszélyhelyzet elhárítását minden szinten. ${ }^{48}$

A veszélyhelyzetet kezelő kormányzati szint által hozott döntéseket a megfelelő időben nyilvánosságra kell hozni a lakosság számára. ${ }^{99} \mathrm{~A}$ válaszlépéseknek szükségesnek és ará-

43 Tong-Zhang, 2020, 148. o.

44 Tong-Zhang, 2020, 149-150. o.

45 A törvény a tufa shijian kifejezést használja, amely angol fordításban emergency incident formában jelenik meg. 46 Veszélyhelyzeti intézkedési törvény 3. szakasz.

47 Veszélyhelyzeti intézkedési törvény 7. szakasz.

48 Veszélyhelyzeti intézkedési törvény 8. szakasz.

49 Veszélyhelyzeti tv. 10. szakasz. 
nyosnak kell lenniük az adott veszélyhelyzet által okozott társadalmi kár jellegének és mértékének megfelelően, és amennyiben több eszköz is rendelkezésre áll, azt kell alkalmazni, amely jobban biztosítja az emberek jogainak és érdekeinek védelmét. ${ }^{50}$

Az egyes veszélyhelyzetek kezelésével a törvény külön fejezete foglalkozik. Ennek rendelkezései alapján a veszélyhelyzet bekövetkeztét követôen haladéktalanul megszervezi az illetékes részlegeket, beveti a vészhelyzeti mentőcsapatokat, és intézkedéseket hoz. ${ }^{51} \mathrm{~A}$ lehetséges intézkedések körét a törvény részletesen meghatározza, természeti és emberi katasztrófa, illetve közegészségügyi esemény esetén például ilyenek a mentés és evakuáció megszervezése, a veszélyesnek ítélt területek kijelölése és elzárása; a sérült közművek helyreállítása; mentési, higiéniai, karanténintézkedések végrehajtása; bizonyos eszközök és létesítmények használatának tiltása vagy korlátozása, bizonyos tevékenységek korlátozása vagy megtiltása; állampolgárok mentési műveletekben való részvételének megszervezése, a speciális tudással rendelkezők számára munkakötelezettség előirása; az élelem, az ivóvíz, az üzemanyagok és más alapvető életszükségletek biztosítása; szigorúbb büntetések bizonyos cselekmények (például árfelhajtás, fosztogatás, védekezés eredményességének veszélyeztetése) esetén. ${ }^{52}$

Amennyiben a társadalmi biztonságot fenyegető esemény következik be, úgy a törvény egészen más eszközöket biztosít, mint például az erőszakos tevékenységben érintett felek erővel történő szétválasztása, épületek, szállító jármûvek, felszerelések, létesítmények és üzemanyagok, gáz-, energia- és vízellátás ellenőrzése, közlekedési utak és helyek lezárása, a helyszínen tartózkodó személyek személyazonosságának igazolása és az érintett nyilvános helyeken végzett tevékenység korlátozása, ideiglenes kordonok felhúzása bizonyos fontos közintézmények körül, illetve egyéb törvényi, határozati és államtanácsi rendelkezések. ${ }^{53}$

Amit fontos még megemlíteni a válságkezelés kapcsán, hogy a veszélyhelyzeti intézkedés képezi az alapját, ám egyéb veszélyhelyzeti jogszabályok is alkothatók specifikus problémák kezelése vonatkozásában. A törvény 2007-es elfogadásától 2015-ig több mint 60 ilyen jogszabály született. ${ }^{54}$ Ilyen a közegészségügyi veszélyhelyzetek sürgős kezeléséról szóló rendelet, ${ }^{55}$ amely a "közegészségügyi veszélyhelyzeteket” úgy határozza meg, mint fertőző betegségek vagy ismeretlen betegségek által okozott jelentős járványhelyzet, étellel és a munkahelyi mérgezéssel kapcsolatos súlyos események, valamint egyéb olyan súlyos közegészségügyi események, amelyek váratlanul következnek be, és súlyos kárt okoznak a társadalom közegészségében. ${ }^{56} \mathrm{~A}$ jogszabály rendelkezései az Államtanács, illetve a helyi, alacsonyabb szintű kormányzati szervek számára biztosítanak felhatalmazást arra, hogy

50 Veszélyhelyzeti tv. 11. szakasz.

51 Veszélyhelyzeti tv. 48. szakasz.

52 Veszélyhelyzeti tv. 49. szakasz.

53 Veszélyhelyzeti tv. 50. szakasz.

54 Shen et al., 2015, 271. o.

55 Az Államtanács által 2003. május 9-én kihirdetett 376. sz. rendelet (Tufa Gonggong Weisheng Shijian Yingji

Tiaoli) a közegészségügyi veszélyhelyzetek sürgős kezeléséről.

56 A közegészségügyi veszélyhelyzetek sürgős kezeléséről szóló rendelet 2. szakasza. 
fellépjen az ilyen veszélyhelyzetek esetén. A fertőző betegségekkel kapcsolatosan több más törvény, illetve rendelet is született..$^{57} \mathrm{Ez}$ az egyik legnagyobb veszélyforrás ma Kínában, különösen az ország elmaradottabb, vidéki régióiban - az ország lakosságának mintegy 60\%-a él ezeken a területeken mint mezőgazdasági munkás, és az elégtelen egészségügyi ellátórendszer miatt különösen kitett a fertőző betegségeknek és járványoknak. ${ }^{58}$

\section{Az alapjogok korlátozására vonatkozó szabályok különleges jogrend idején}

A kínai alkotmány külön fejezetben sorolja fel az állampolgárok jogait és kötelezettségeit. Meglehetősen kevés védelmet élveznek ugyanakkor ezek a jogok, és maga az alkotmány is tartalmaz egy olyan klauzulát, amely kimondja az államérdek elsőbbségét: az állampolgárok csak annyiban gyakorolhatják jogaikat, amennyiben ezzel nem sértik az állam vagy a közösség érdekeit, más állampolgárok jogait. ${ }^{59} \mathrm{Ez}$ azt jelenti, hogy az állam rendes múködése során különleges felhatalmazás nélkül is igen széles lehetőség nyílik az állam számára az alapjogok korlátozására. ${ }^{60}$

Mindezek fényében igen meglepő, hogy a különleges jogrendi szabályozásban komoly aggodalomként jelentek meg a hatáskörükön túlterjedő állami szereplők. Mind az Ostromállapot tv., mind a Veszélyhelyzeti tv. előírják, hogy a kivételes intézkedéseket csak meghatározott feltételekre kell korlátozni, és arányosnak kell lenniük a veszéllyel. ${ }^{61} \mathrm{~A}$ kettô közül az Ostromállapot tv. sokkal komolyabb jogkorlátozó intézkedéseket tartalmaz, például lehetôvé teszi az utcai gyülekezés, demonstráció betiltását, a sztrájktilalmat, a sajtóembargót, a hírközlés, a postai szolgáltatások és a távközlés feletti ellenőrzést, az országba történő belépés és az abból történő kilépés ellenőrzését, valamint bármilyen egyéb tevékenység betiltását. ${ }^{62}$ Lehetőség nyílik továbbá a forgalom ellenőrzésére, a kijárási tilalom bevezetésére, a fegyverek és más veszélyes eszközök ellenőrzésére, a lakóingatlanok, ingóságok ideiglenes használatba vételére. ${ }^{63} \mathrm{~A}$ törvény jelentős és széles jogköröket biztosít a szükségállapotban érintett rendőröknek, fegyveres rendőröknek és katonáknak, például ellenőrzéseket, kutatásokat és igazoltatásokat folytathatnak, bizonyos esetekben azonnal őrizetbe vehetnek embereket, és tevékenységük során akár lőfegyvert is használhatnak. ${ }^{64}$

57 Ezeket bővebben lásd: www.loc.gov/law/help/health-emergencies/china.php (Letöltve: 2020. december 15.).

$58 \mathrm{Hu}-\mathrm{Chen}-\mathrm{Kuai}, 2018$.

59 Alkotmány 51. cikk.

60 Deloise, 2010, 405. o.

61 Veszélyhelyzeti tv. 11. szakasz, valamint Ostromállapot tv. 7. szakasz.

62 Ostromállapot tv. 13. szakasz.

63 Ostromállapot tv. 14-17. szakasz.

64 Ostromállapot tv. 21-30. szakasz. 
A jóval enyhébb esetek kezelésére megalkotott Veszélyhelyzeti tv. szúkebb körben biztosít lehetőséget az alapjogok korlátozására. A törvény lehetővé teszi a magánszemélyek és a jogi személyek ingatlanjainak ideiglenes használatbavételét a helyi kormányzati szervek által. ${ }^{65} \mathrm{~A}$ hatóságoknak lehetőségük van a veszélyes területek lezárására, a forgalom korlátozására, bizonyos létesítmények használatának a korlátozására vagy tiltására, valamint a lakosság bevonására a kárelhárításba. ${ }^{66}$

Az alapjogok korlátozásának megfelelő ellenőrzése hangsúlyos szempont volt a vonatkozó jogszabályok elfogadása során is. A szükségállapot jogrendszerbe történő bevezetése kapcsán érvként merült fel az, hogy az új rendelkezés alapján történő felhatalmazás védi az állampolgárok jogait is. ${ }^{67} \mathrm{~A}$ Veszélyhelyzeti tv. elfogadása során törölték azt a rendelkezést a törvény szövegéből, amely bírsággal fenyegette a tömegkommunikációs csatornákat abban az esetben, ha azok hatósági engedély nélkül tesznek közzé információkat, vagy hamis információkat közvetítenek. ${ }^{68}$

\section{A koronavírus-járványra adott állami reakció}

A kínai Vuhan városa mint a Covid-19-járvány kiindulópontja került be a hírekbe. Szemben a 2003-as SARS-járvánnyal, ezt nem sikerült a kínai hatóságoknak időben megfékezniük, és 2020 márciusában a WHO világjárvánnyá nyilvánította azt.

Kínában nem került bevezetésre szükségállapot, ugyanakkor a Veszélyhelyzeti tv. szerinti legmagasabb, egyes szintű (különösen komoly) veszélyhelyzet került elrendelésre, amely alapján a tartományok meghozhattak olyan intézkedéseket, mint városok és utak lezárása. A járványokra a nyugati országoknál alapvetően jobban felkészült kínai jogrendszerben számos jogszabály tartalmaz olyan rendes intézkedéseket is, amelyek a különleges jogrend nélkül is igénybe vehetôk. Például felhatalmazást adtak a karanténszabályok bevezetésére, a fertőzöttek és külföldről érkezők megfigyelésére, a járvánnyal összefüggésben egészségügyi igazolások kiállítására. Az intézkedések részeként betiltották a vadhús fogyasztását, ugyanis feltehetően ezen az úton jutott be a denevérekben található koronavírus az emberi szervezetbe, eloidézve a járványt. ${ }^{69} \mathrm{Az}$ intézkedések részeként 76 napos lezárás alá vonták Vuhan városát, ahol a tömegközeledést is felfüggesztették. Később egész Hubei tartományra kiterjesztették ezt a lezárást. Az intézkedések mellett nagy szerepe volt az effektív járványkezelésben annak is, hogy a lakosság igen nagy számban tartotta be az előírásokat, például a maszkviselésre vagy a távolságtartásra vonatkozóan. Ebben minden bizonnyal nagy szerepe volt a SARS-járványról élő emlékeknek is. ${ }^{70}$

65 Veszélyhelyzeti tv. 12. szakasz.

66 Veszélyhelyzeti tv. 49. szakasz.

67 Deloise, 2009, 351. 0.

68 Tong-Zhang, 2020, 35. o.

69 Zhengfa-Wanqiang, 2020.

70 Burki, 2020, 1240. o. 
A kormányzat számos olyan rendelkezést hozott, amelyek a vírus terjedésének lassítását szolgálták. Így például támogatták az otthon maradás politikáját, betiltották a tömeges öszszejöveteleket, lemondták vagy elhalasztották a nagy nyilvános rendezvényeket, és bezárták az iskolákat, egyetemeket, kormányhivatalokat, könyvtárakat, múzeumokat és gyárakat. Ezzel együtt megpróbálták korlátozni a belföldi utazásokat is.$^{71}$ Problémát okozott, hogy a járvány terjedése idején ünnepelték a kínai újévet, amikor a világ számos részén, illetve az országban távolabb élố kínaiak hazautaznak a családjaikhoz. Mivel sokan csak egy hetet töltenek családjaikkal - amely rövidebb, mint a fertőzés és a tünetek megjelenése közötti leghosszabb ismert lappangási időszak -, a hatóságok az ünnepek meghosszabbításával próbálta elejét venni a korai hazautazásoknak. A védekezés során nemcsak a betegeket, de a tünetmentes fertőzötteket és enyhe tüneteket mutatókat is elkülönítették szükségkórházakban, amelyeket például stadionokból és konferenciaközpontokból alakítottak ki. ${ }^{72}$

2020 tavaszán már enyhíteni lehetett a bevezetett korlátozásokon, ám a vírus nem túnt el teljes egészében az országból ezután sem. ${ }^{73} \mathrm{Az}$ intézkedések eredményeként 2020 júniusára mindössze csak a fôvárosba, Pekingbe, illetve Liaoning és Xinjiang tartományokba jutott el a fertózés. Ebben a hónapban egy fővárosi nagykereskedelmi piacról indult el újra a járvány terjedése, ismét lezárásokat eredményezve Pekingben. ${ }^{74}$

Több probléma is adódott azonban a kínai védekezéssel. Először is, hogy a korai védekezés során a titkolózás és a szervek lassú reagálása miatt csak 2020. január végén került nyilvánosságra az a tény, hogy a vírus emberról emberre is képes terjedni, holott az erről szóló információk már decemberben is rendelkezésre álltak. Ebben a veszélyhelyzeti szabályozás következetlensége is szerepet játszott: míg a Veszélyhelyzeti tv. és a közegészségügyi veszélyhelyzetekre vonatkozó állami terv szerint minden helyi, illetve a központi kormányzatok megfelelő szervei is közzétehetnek figyelmeztetéseket, addig a fertőző betegségek megelőzéséről szóló törvény szerint az Államtanács közegészségügyért felelős szerve és a tartományi kormányzat tehet közzé korai figyelmeztetést. Ráadásul utóbbi törvény rendelkezéseit nem is lehet alkalmazni ismeretlen eredetû́ betegség esetén, amíg az Államtanács azt jóvá nem hagyja, jelentős időveszteséget okozva ezzel. Végül a Veszélyhelyzeti tv.-ből hiányzik az átfogó felső szintú tervezés. A veszélyhelyzeti terv elindításáért felelős szerv megjelölése következetlen. A törvény felhatalmazza a megyei szint feletti helyi kormányokat, hogy kezdeményezzék a veszélyhelyzeti tervek alkalmazását, de a fertőző betegségek megelőzéséről szóló törvény előirja, hogy a megyei szint feletti kormányok csak akkor alkalmazhatják a veszélyhelyzeti tervet, ha az Államtanács vagy a tartományi közegészségügyi osztálya ehhez hozzájárult. ${ }^{75}$

71 Tangcharoensathien et al., 2021.

72 Chen et al., 2020, 765. o.

73 Tangcharoensathien et al., 2021.

74 Elérhető: www.bbc.com/news/av/world-asia-china-54034809 (Letöltve: 2020 . december 15.).

75 Zhengfa-Wanqiang, 2020. 


\section{A különleges jogrend a gyakorlatban, viták és kihívások}

A Kínai Népköztársaság 1949-es kikiáltása után totalitárius jegyeket magán viselő államként a hadsereg számos alkalommal vett részt a válságok kezelésében, ám ennek vonatkozásában nem léteztek külön normatív szabályok vagy jogi alap. ${ }^{76}$ Különleges jogrendről ezért csak a Mao Ce-tung halála után elfogadott 1982-es alkotmány szerint lehetett beszélni, ${ }^{77}$ amikor a Teng Hsziao-ping fémjelezte reformidőszak megindult. A különleges jogrend legelső alkalmazására az 1989-es Tienanmen téri diáklázadás, illetve az ezzel egy időben zajló tibeti szektariánus konfliktus során került sor. Április 27-én a demokráciát követelő diákok a Tienanmen térre vonultak, majd tárgyalásokba kezdtek a kormánnyal. Ahogy az események elhúzódtak, a megállapodáspárti kormánytagok háttérbe szorultak a Li Peng miniszterelnök vezette keményvonalasok ellenében. Május 20-ára az ő javaslatára Pekingben kihirdették az ostromállapotot. Ezzel nagyjából egy időben zajlottak a tibeti buddhista lakosság zavargásai is, amelyekre válaszul március 7-én szintén bevezetésre került az ostromállapot, amely csak a terület fôvárosát, Lhászát érintette. Pekingben betiltották a gyülekezéseket, és a Népi Felszabadító Hadsereg több tízezer katonáját vezényelték ki a Tienanmen térre, hivatalosan az ostromállapoti szabályok betartatása érdekében, ám a valóságban ez súlyos vérengzéshez vezetett, amikor a katonák és a diákok összecsaptak. Tibetben Hu Jintao helyi párttitkár, későbbi államelnök hozta meg a megfelelő döntéseket, és figyelmeztette a zavargások résztvevőit a törvény megsértésének súlyos következményeire. ${ }^{78}$

Különösen a pekingi Tienanmen téri események komoly nemzetközi és hazai kritikákat váltottak ki. A kínai vezetés komoly erőt fordított rá, hogy az ostromállapot bevezetésének jogosságát igazolja a közvélemény és a kritikusok eloottt, a különleges jogrend alkalmazásának alkotmányos kereteire történő hivatkozással. A kritikák ugyanakkor rákényszerítették a kormányzatot, hogy részletesebb szabályozást dolgozzon ki, így erősebb jogi alapot adva a különleges jogrendi intézkedéseknek. Ez lett az 1996-os Ostromállapot tv. ${ }^{79} \mathrm{~A}$ kínai különleges jogrendi rendszert a 2003-as SARS-járvány tette próbára, amely Dél-Kínából indult el. A központi kormányzat különféle különleges felhatalmazásokkal hozott rendkívüli rendeleteket, ugyanakkor ostromállapot hivatalosan nem került bevezetésre. Szigorú büntetőjogi szankciókat hoztak például a vírus tudatos terjesztése és a rémhírterjesztés kapcsán. Ugyan az intézkedések jogszerüsége és jogi megalapozottsága ebben az esetben aligha vonható

76 Így például az ország létrehozását követően annak stabilizálásában - a megfelelő civil szervek hiányában -, illetve a kulturális forradalomban az államszervek szétforgácsolódását követően. 1976-ban a Tienanmen téri demonstráció feloszlatásakor is mindenféle jogi háttér nélkül (Deloise, 2009, 348. o.).

77 Fontos megemlíteni, hogy a kommunista államot megelőzően múködő Kínai Köztársaság (a mai Tajvan) ismerte és alkalmazta ezt az eszközt: 1948 és 1987 között folyamatosan szükségállapot volt Tajvanon. Elérhető: www.lowyinstitute.org/the-interpreter/end-martial-law-important-anniversary-taiwan (Letöltve: 2020. december 15.).

78 Deloise, 2009, 348-349. o.

79 Deloise, 2009, 350. o. 
kétségbe, azok ad hoc mivolta komoly kritikákat eredményezett. 2004-ben a tapasztalatok alapján az ostromállapotot felváltotta a szükségállapot az alkotmányban. ${ }^{80}$

Az új jogintézményt a 2007-ben elfogadott Veszélyhelyzeti tv. töltötte ki tartalommal. Eredetileg a szükségállapoti törvény megalkotására születtek javaslatok, de ennek képviselői alulmaradtak, mivel a veszélyhelyzetek sokkal gyakoribb problémát jelentettek a ritkán bekövetkező nagyobb válsághelyzeteknél, és a törvény sokkal mérsékeltebb, a normális múkködéstől jóval kevésbé eltérő eszközöket igényelt. ${ }^{81}$ Ennek a törvénynek a gyakorlati alkalmazása meglehetôsen nagy, mintegy évi 80 ezer társadalmi biztonságot veszélyeztető esemény (feltehetôen tüntetések és tiltakozások) történik az országban évente. A válságkezelés alsóbb jogi szintekre történő delegálása abból a szempontból is tudatos volt, hogy a különleges jogrend ugyan egyértelmú jogi helyzetet teremt ezek kezelésére, de általánossá válása komoly problémákhoz vezethet. ${ }^{82}$ Bizonyos esetekben politikai okokból nem került bevezetésre a különleges jogrend, habár eszközeit - igaz veszélyhelyzetként - alkalmazták, így például 2008-ban, a pekingi olimpia évében, amikor földrengés történt Szecsuan tartományban, és zavargásokra került sor Tibet és Xinjiang tartományokban. ${ }^{83}$ A Népi Fegyveres Rendőrségről szóló törvény ezt követően módosításra került, az Ostromállapot tv.-ben foglaltakhoz hasonló felhatalmazást adva a testületnek a zavargások kezelésére. ${ }^{84}$

A törvények bírósági felülvizsgálata nem ismert Kínában. Az Országos Népi Gyúlés egyik bizottsága jogosult normakontrollra, ám ezalól az Országos Népi Gyűlés, illetve annak Állandó Bizottsága által hozott jogszabályok kivételt képeznek. A gyakorlatban az Államtanács által hozott közigazgatási határozatokat és rendeleteket is mindig az alkotmánnyal összhangban állónak tekintik. Ugyan az illetékes törvényhozási bizottságnak megvan a lehetősége, hogy az alsóbb szintư közigazgatási szervek által hozott határozatokat alkotmányellenesnek nyilvánítsa, a gyakorlatban még sosem élt ezzel a jogával. ${ }^{85}$ Mindezek mellett a bíróságok végrehajtó hatalom felett gyakorolt kontrollja a kínai politikai rendszerben erősen megkérdőjelezhető. ${ }^{86}$

\section{5. Összegzés}

Az alábbi táblázat tartalmazza a kínai különleges jogrendi esetkörökkel kapcsolatos legfontosabb szabályozásokat.

80 Deloise, 2009, 350-352. o.

81 Deloise, 2009, 352. 0.

82 Deloise, 2009, 354-355. o.

83 Deloise, 2009, 355-356. o.

84 Deloise, 2009, 355-356. o.

85 Elérhető: https://npcobserver.com/2018/01/19/recording-review-an-introduction-to-constitutional-reviewwith-chinese-characteristics/ (Letöltve: 2020. december 15.).

86 Deloise, 2009, 343. o. 


\begin{tabular}{|c|c|c|}
\hline & Szülkségállapot & Védelmi állapot \\
\hline Szabályozás szintje & \multicolumn{2}{|c|}{$\begin{array}{l}\text { Alkotmányos, törvényi } \\
\text { (Veszélyhelyzeti tv., Ostromállapot tv., Honvédelmi törvény) }\end{array}$} \\
\hline Elrendelési okok & $\begin{array}{l}\text { Különösen súlyos veszélyhelyzet, amely } \\
\text { komoly veszélyt jelent az emberek életére } \\
\text { vagy vagyonbiztonságára, a nemzetbizton- } \\
\text { ságra, a közbiztonságra, a környezetbizton- } \\
\text { ságra vagy a társadalmi rendre } \\
\text { (a hongkongi és makaói alaptörvényekben } \\
\text { olyan zûrzavar, amely a nemzeti egységet } \\
\text { vagy biztonságot veszélyezteti, és a helyi } \\
\text { kormányzat nem tudja azt megfékezni). }\end{array}$ & $\begin{array}{l}\text { Külső fegyveres támadás } \\
\text { az ország ellen, } \\
\text { nemzetközi közös védelmi } \\
\text { kötelezettségnek való } \\
\text { megfelelés. }\end{array}$ \\
\hline Elrendelés & \multicolumn{2}{|c|}{$\begin{array}{l}\text { Az Országos Népi Gyűlés Állandó Bizottsága dönt a bevezetésről, az ál- } \\
\text { lamelnök hirdeti ki. } \\
\text { A szükségállapotot a közvetlenül a központi kormány igazgatása alá tartozó } \\
\text { területeken az Államtanács vezeti be. }\end{array}$} \\
\hline Felhatalmazott & \multicolumn{2}{|c|}{ Az Államtanács (központi kormány), tartományi és helyi szervek. } \\
\hline Gyakorlati esetek & \multicolumn{2}{|l|}{$\begin{array}{l}1989 \text { - Tienanmen téri és tibeti események; } \\
2003 \text { - SARS-járvány; } \\
2008 \text { - tibeti és xinjiangi zavargások }\end{array}$} \\
\hline $\begin{array}{l}\text { Különleges jog- } \\
\text { rendnek nem mi- } \\
\text { nősülő rendkívüli } \\
\text { helyzet }\end{array}$ & \multicolumn{2}{|l|}{ Veszélyhelyzet } \\
\hline
\end{tabular}

26. táblázat

Kina különleges jogrendi szabályozásának összefoglalása

Forrás: a szerző saját összeállitása

A Kínai Népköztársaság jogrendszerében a különleges jogrend intézménye meglehetősen új, csak a Mao Ce-tung halála utáni reformidőszakban került be az 1982-ben elfogadott alkotmányba. Előtte, különösen az 1949-es alapításkor és az 1970-es években, a kulturális forradalom idején az állam egyfajta állandó, nem hivatalos különleges jogrendben múködött, ahol a mindennapi ügyekben nagy szerep jutott a hadseregnek. ${ }^{87} \mathrm{~A}$ különleges jogrend - annak ellenére, hogy az állam mind a mai napig a rendes jogalkotás keretében is jelentős 
hatalmat gyakorol korlátozott felügyelet mellett - mégis felértékelödött, és többször a jogalkotás fókuszába került. Ennek többféle magyarázata és oka van, ezek közül kiemelendő, hogy az 1980-as évek óta tartó reform egyik fontos pillére a jogi reform, és bár Kína az elmúlt időszakban az átlagnál rosszabb, az alsó harmadban lévő helyezést ért el jogállamisági vizsgálatokon, folyamatosan javít a helyezésén. ${ }^{88} \mathrm{~A}$ különleges jogrend hatalomkoncentráló természete is hasznos eszközzé teszi azt, és eszközül szolgálhat a Kínai Kommunista Párt által meghatározott értékek védelméhez. Mindezek mellett a különleges jogrend bizonyos hatalomlimitáló aspektusai a liberalizációt támogatók számára is szimpatikus eszközzé teszik azt. ${ }^{89}$ Mindezek ellenére a különleges jogrend jelenléte a kínai jogrendszerben továbbra is paradoxon, tekintve, hogy ennek alkalmazása nélkül, a rendes müködés keretei között is szinte korlátlan hatalommal bír a kormányzat a felmerülő rendkívüli helyzetek kezelésére.90

A kínai jogrendben az alkotmány kétféle különleges jogrendi eszközt határoz meg: a szükségállapotot, illetve a hadiállapotot. Mindkettő csak röviden, a bevezetésre jogosult szerv kapcsán kerül említésre az alkotmányban. A bevezetésról mindkét esetnél a törvényhozás, az Országos Népi Gyúlés Állandó Bizottsága dönt, és az államelnök hirdeti azt ki. A közvetlenül a központi kormány, az Államtanács irányítása alá tartozó területeken maga az Államtanács dönthet a szükségállapot alkalmazásáról. Az ország két speciális igazgatású területe, Hongkong és Makaó esetén az Országos Népi Gyúlés Állandó Bizottsága dönt a szükségállapot bevezetéséről, amennyiben a helyi kormányzat képtelennek bizonyul a súlyos zavar kezelésére. A hadiállapotot külső fegyveres támadás, illetve nemzetközi közös védelmi kötelezettségnek való megfelelés esetén lehet elrendelni, a Honvédelmi tv.-ben foglalt részletszabályai meglehetôsen általánosak.

A szükségállapot szabályait két törvény, az Ostromállapot tv., illetve a veszélyhelyzeti intézkedésekről szóló törvény tartalmazza. Ez jóval kidolgozottabb jogintézmény, elrendelésére olyan különösen súlyos veszélyhelyzet esetén kerülhet sor, amely komoly veszélyt jelent az emberek életére vagy vagyonbiztonságára, a nemzetbiztonságra, a közbiztonságra, a környezetbiztonságra vagy a társadalmi rendre. Az Ostromállapot tv. tartalmazza a szükségállapotra vonatkozó szabályokat, amelyek jóval szigorúbbak, míg a veszélyhelyzeti intézkedési törvény elsősorban az ennél enyhébb veszélyhelyzetekre vonatkozóan szabályoz. A veszélyhelyzet ugyan nem különleges jogrend, mégis különleges felhatalmazást ad. A rendszerben egy erős fokozatosság figyelhető meg: a súlyosságában négy fokozatra osztott veszélyhelyzet legkomolyabb, különösen súlyos fokozata esetén van lehetőség szükségállapotot bevezetni. A felhatalmazás megoszlik az Államtanács, illetve a helyi kormányzati szervek között, amiben az a felismerés rejlik, hogy utóbbiak eredményesebben tudják kezelni a helyi problémákat.

88 Elérhető: https://worldjusticeproject.org/rule-of-law-index/country/2020/China/ (Letöltve: 2020. december 15.).

89 Deloise, 2009, 344-345. o.

90 Deloise, 2010, 407. 0. 
A kínai jogrendszer múködéséből kifolyólag az állam számára nem okoz különösebb problémát az alapjogok korlátozása a rendes múködés során, az alkotmány deklaráltan az egyéni jogok gyakorlása elé helyezi az államérdeket. Ennek ellenére érdekes módon a különleges jogrend esetén a jogalkotó kimondottan igyekezett az állami beavatkozás mértékét csökkenteni, a vonatkozó törvények például tartalmazzák a szükségesség-arányosság kritériumait az intézkedések meghozatala kapcsán, illetve garanciákat a jogok korlátozása kapcsán. Ezt a törvények liberalizációpárti kommentátorai igyekeznek úgy magyarázni, mint az államhatalom korlátozásának csírái a későbbi kínai jogfejlődésben.

A különleges jogrend gyakorlati alkalmazása kapcsán meglehetősen rossz tapasztalatok vannak a nemzetközi közösség emlékezetében. Az 1989-es Tienanmen téri események, illetve ezzel egy időben a tibeti zavargások elfojtása ostromállapot bevezetésével történt, amelyet ekkoriban még a hadsereg elsődlegessége jellemzett. A tapasztalatok alapján elfogadott Ostromállapot tv. próbálta korlátozni ezt, és biztosabb jogi alapot adni a későbbi intézkedéseknek. A 2003-as SARS-járvány kezelése újra komoly kritikákra adott okot, ami az alkotmány reformjához, a szükségállapot megteremtéséhez, illetve a többszintú veszélyhelyzeti válságkezelés kialakításához vezetett. Itt már jelentős megközelítésbeli eltérés mutatkozott, a hadsereg szerepét mérsékelték, és elsősorban a civil közigazgatás kezébe adtak eszközöket. Köszönhetően a SARS-járvány tapasztalatainak, illetve annak, hogy az ország járványügyi szabályozása meglehetősen kidolgozott - a fejletlenebb vidéki területeken gyakrabban előforduló járványok okán -, az ország az átlagnál eredményesebben tudta kezelni a koronavírus-járványt. Rámutatott azonban a krízis a szabályozás következetlenségeire, a tervezési rendszer - amely a veszélyhelyzet és így a különleges jogrend alapja - hibáira.

A kínai és a magyar szabályozás összehasonlítása nagyon nehéz feladat, hiszen a két ország rendes múködése is jelentősen eltér egymástól. Elmondható, hogy a különleges jogrendi esetkörök száma jóval alacsonyabb Kínában a jelenlegi magyar szabályozásnál. Az Alaptörvény kilencedik módosítása alapján eloálló szisztémában az eszközök száma azonos lesz (a kínai kvázi különleges jogrend veszélyhelyzetet is ideszámítva), és a típusuk is, ám a múködési elvük eltérő. Míg idehaza a szükségállapot csak az alkotmányos rend megváltoztatásának kísérletét és a tömeges erőszakos cselekményeket foglalja magában, addig a kínai szabályozásban a szükségállapot egyúttal a magyar rendszer szerinti veszélyhelyzetet is magában foglalja. Ott a megosztás logikája az, hogy a legsúlyosabb veszélyhelyzetek esetén alkalmazható különleges jogrend, egyébként csak az enyhébb veszélyhelyzeti eszközök vehetôk igénybe. A kínai veszélyhelyzetbe következésképp a természeti és emberi katasztrófák, balesetek, fertőző betegségek mellett a társadalmi rend ellen irányuló kisebb súlyú és intenzitású cselekmények is beletartoznak.

Az elrendelés kapcsán mind idehaza, mind Kínában nagy jelentőség jut a törvényhozásnak, a szükségállapotot és a hadiállapotot ez a szerv rendelheti el. A veszélyhelyzet elrendelésére Kínában a helyi (megyei, prefektúrai, tartományi) kormányzat, illetve a legsúlyosabb esetekben a központi kormány jogosult. A kínai rendszerben így - az ország 
területének méretéből adódóan - jóval nagyobb szerep jut a helyi kormányzati szerveknek a rendkívüli események kezelésében.

Egyéb aspektusaiban a szabályozás a jogrendszer komoly eltérőségei, illetve a politikai berendezkedés különbözősége miatt nem hasonlítható össze érdemben. Összességében elmondható, hogy Kínában nagy hangsúlyt helyezett az elmúlt évtizedekben az állam arra, hogy ezeket a szabályokat minél alaposabban kidolgozza, főlleg a veszélyhelyzetek tömegességére való tekintettel. A rendszer a koronavírus-járvány kapcsán bizonyította múködőképességét, ám számos hiba is feltárásra került, különösen a korai védekezés kapcsán.

\section{Irodalomjegyzék}

BURKI, T. (2020) 'China's Successful Control of COVID-19', The Lancet Infectious Diseases, 20(11), 1240-1241. O.

Chen, S., YAng, J., Yang, W., WANG, C., Bärnighausen, T. (2020) 'COVID-19 Control in China during Mass Population Movements at New Year', The Lancet, 395(10226), 764-766. o.

DelisLE, J. (2009) 'States of Exception in an Exceptional State: Emergency Powers Law in China' in Ramraj, V. V., Thiruvengadam, A. K. (szerk.) Emergency Powers in Asia. Exploring the Limits of Legality. 1. kiadás. Cambridge: Cambridge University Press

Delisle, J. (2010) 'Security First? Patterns and Lessons from China's Use of Law To Address National Security Threats', Journal of National Security Law \& Policy, (4)2, 397-436. o.

Hu, J., CHEN, C., KuAI, T. (2018) 'Improvement of Emergency Management Mechanism of Public Health Crisis in Rural China: A Review Article', Iran Journal of Public Health, 47(2), 156-165. o.

JIANFU, H. (2004) The Revision of the Constitution in the PRC. A Great Leap forward or a Symbolic Gesture? [Online]. Elérhető: https://journals.openedition.org/chinaperspectives/2922 (Letöltve: 2020. december 15.)

Lu, X., XuE, L. (2016) 'Managing the Unexpected: Sense-making in the Chinese Emergency Management System', Public Administration, 94(2), 414-429. o.

Shen, W., JiAng, L., ZANG, M., MA, Y., JiAnG, G., HE, X. (2015) 'Practical Experiences and Lessons of Medical Response to Major Disasters in China', Hong Kong Journal of Emergency Medicine, 22(5), 270-280. o.

Shigong, J. (2014) 'Chinese-Style Constitutionalism: On Backer's Chinese Party-State Constitutionalism', Modern China, 40(2), 133-167. o.

SPItzer, J. (2020) 'Különleges jogrendi szabályozás a kínai, a japán, a dél-koreai és a szingapúri jogrendszer sajátosságai között’ in Farkas, Á., Kelemen, R. (szerk.) Szkülla és Kharübdisz között - Tanulmányok a különleges jogrend elméleti és pragmatikus kérdéseiról, valamint nemzetközi megoldásairól. 1. kiadás. Budapest: Magyar Katonai Jogi és Hadijogi Társaság 
Tangcharoensathien, V., Bassett, M. T., Meng, Q., Mills, A. (2021) Are Overwhelmed Health Systems an Inevitable Consequence of Covid-19? Experiences from China, Thailand, and New York State [Online]. Elérhető: www.bmj.com/content/372/bmj.n83 (Letöltve: 2020. december 15.) ToNG, X., ZHANG, H. (2020) China's Emergency Management. 1. kiadás. Szingapúr: Springer Zhengfa, Z., WANQIANG, W. (2020) 'Amendment of China's Biotechnology Laws in Relation to the Prevention and Containment of the COVID-19 Pandemic', Biotechnology Law Report, (39)6, 458-467. o. 